\title{
DWA NIEZNANE ŚREDNIOWIECZNE DOKUMENTY DO DZIEJÓW LWOWSKIEGO KOŚCIOLA ŚW. DUCHA
}

Zaniedbane dawniej badania nad dziejami Kościoła halicko-lwowskiego, także te traktujące o instytucjonalnych i organizacyjnych aspektach jego funkcjonowania, zyskały ostatnimi czasy na popularności. Studia te, oparte na pogłębionej kwerendzie, prowadzonej zarówno w Archiwum Archidiecezji Lwowskiej z siedzibą w Krakowie, jak również w dostępnych dzisiaj archiwach i bibliotekach na terenie Ukrainy, poszerzyły istotnie skromną przecież bazę źródłową ${ }^{1}$. Do odkrytych na nowo zabytków należy rękopis przechowywany dzisiaj w Naukowej Bibliotece im. W. Stefanyka Narodowej Akademii Nauk Ukrainy we Lwowie pod sygnaturą: Fond 5, op. 1, spr. $2155^{2}$, zawierający m.in. sporządzone z inicjatywy

* Renata Trawka-dr historii; Zakład Historii Średniowiecznej i Nordystyki Starszej Uniwersytetu Rzeszowskiego; e-mail: rentka@wp.pl

${ }^{1}$ Zob. uwagi J. A. Spieża, Trzy niedocenione czternastowieczne dokumenty z archiwum dominikanów w Żółkwi, w: Narodziny Rzeczypospolitej. Studia z dziejów średniowiecza i czasów wczesnonowożytnych, t. I-II, red. W. Bukowski, T. Jurek, Kraków 2012, t. II, s. 1305-1329, tu s. 1305. Przeglądu źródeł do dziejów archidiecezji halicko-lwowskiej dokonali: J. Kania, Katalog mikrofilmów Ośrodka Archiwów, Bibliotek i Muzeów Kościelnych przy Katolickim Uniwersytecie Lubelskim, „Archiwa, Biblioteki i Muzea Kościelne” (dalej: ABMK), 51 (1985) s. 5-116; S. Tylus, Fundacje kościołów parafialnych $w$ średniowiecznej archidiecezji lwowskiej, Lublin 1999, s. 34-37; M.T. Zahajkiewicz, Zagadnienie gromadzenia dokumentacji źródłowej do badań nad dziejami Kościoła łacińskiego na wschodnich ziemiach kresowych dawnej Polski, ABMK, 61 (1992) s. 145-166. O rezultatach poszukiwań w archiwach ukraińskich zob. m.in.: Dokumenty Kościoła rzymskokatolickiego Archidiecezji lwowskiej w zasobach Centralnego Państwowego Archiwum Historycznego Ukrainy we Lwowie. Inwentarze, opr., wstępem opatrzył i podał do druku ks. J. Wołczański, Kraków 2007.

${ }^{2}$ Rękopis w wersji cyfrowej dostępny jest na stronie Zakładu Narodowego im. Ossolińskich: http://bazy.oss.wroc.pl/kzc/wyniki_pl.php?RL-000458 (dostęp: 28.04.2014). Przed wojną korzystał z niego A. Gilewicz, Stanowisko i działalność gospodarcza Władystawa Opolczyka na Rusi w latach 1372-1378, Lwów 1929 (Prace historyczne wydane ku uczczeniu 50-lecia Akademickiego Koła Historyków Uniwersytetu Jana Kazimierza we Lwowie 1878-1928), zwł. s. 14 n., a dziesięć lat temu o istnieniu tego rękopisu przypomniał M. Wilamowski, Strepa (Strzemię) Jakub, w: Polski 
Adama Mniszkowskiego, prepozyta szpitala Św. Ducha i prebendarza kaplicy św. Katarzyny na Zamku Niskim we Lwowie, kopie kilku dokumentów z XIV i XV wieku. Wśród nich znajdują się dwa niewydane dotąd dyplomy dotyczące uposażenia rektora lwowskiego kościoła Św. Ducha ${ }^{3}$.

Pierwszy z publikowanych niżej dokumentów - wystawiony przez arcybiskupa halickiego Jakuba Strepę 9 kwietnia 1399 r. w Wiszni ${ }^{4}$ - ma charakter poświadczeniowy. Informuje o donacji uczynionej przez Michała z Malechowa, który zapisał rektorowi kościoła szpitalnego Św. Ducha we Lwowie jedną kope groszy ruskich czynszu rocznego (płatnego w dniu św. Marcina) na dochodach z karczmy w Malechowie, zobowiązując się przy tym do jej naprawy i ulepszenia $^{5}$. Motywy, jakimi kierował się darczyńca, zostały ujęte stereotypowo: darowi-

Stownik Biograficzny (dalej: PSB), t. 44, Kraków 2006-2007, s. 318-324 (zob. niżej przyp. 5). Opis jego zawartości zamieszczony został w: Informator o polonikach $w$ zbiorach rękopiśmiennych Lwowskiej Narodowej Naukowej Biblioteki Ukrainy im. Wasyla Stefanyka, cz. I, opr. M. Matwijów, E. Ostromęcka, Wrocław 2010, s. 64 oraz R. Trawka, Dokument Wtadystawa Opolczyka dla najstarszego lwowskiego szpitala, w: Ecclesia - Regnum - Fontes. Studia z dziejów średniowiecza, Warszawa 2014, s. 240-250, tu s. 246-248.

${ }^{3}$ Kościół Św. Ducha - jego początki i uposażenie - badano w ścisłym związku z dziejami najstarszego szpitala lwowskiego. Spośród ważniejszych pozycji wymienić należy prace takich autorów jak: C.W. Rasp, Beschreibung des städtlichen Bürgerspitals St. Lazar in Lemberg „Archiv für österreichische Geschichte", 43 (1870) s. 505-544; J. Skoczek, Ze studiów nad średniowiecznym Lwowem, Lwów 1928, s. 93-105 [347-359]; M.A. Bladye', Szpital św. Ducha we Lwowie, „Archiwum Historii i Filozofii Medycyny”, 62 (1999) z. 1/2, s. 51-66; M. Słoń, Szpitale lwowskie w wiekach średnich, „Przegląd Historyczny”, 85 (1994) z. 3, s. 221-237. W 1998 r. postulat wnikliwszej kwerendy źródłowej prowadzonej pod kątem uposażenia szpitala zgłosiła O. Denys, Szpital Świętego Ducha we Lwowie, w: Szpitalnictwo w dawnej Polsce, red. M. Dąbrowska, J. Krupp, Warszawa 1998 (Studia i Materiały z Historii Kultury Materialnej, 66), s. 173-184, tu s. 177. Zob. też: J. Szyszka, Monarsze nadania dóbr ziemskich na rzecz mendykantów i innych instytucji kościelnych $w$ ziemi lwowskiej $w$ średniowieczu, w: Inter oeconomiam caelestem et terrenam. Mendykanci a zagadnienia ekonomiczne, red. W. Długokęcki, T. Gałuszka, R. Kubicki, A. Zajchowska, Kraków 2011 (Studia i Źródła Dominikańskiego Instytutu Historycznego w Krakowie, 9), s. 239-257, tu s. 247. Tej ostatniej pracy nie zdążyła już uwzględnić Oksana Potymko, która zebrała i podsumowała dorobek historiografii poświęconej szpitalnictwu lwowskiemu, a w tym i kościołowi Św. Ducha: eadem, Развиток медицины у Львові в ХIV-ХVIII ст.: література, проблемь, дискусії, Львів 2012. Zob. też wcześniejsze prace autorki: Шпиталі Львова XIV-XVIII століть (Історіографічні спостереження), „Записки Наукового Товариства імені Шевченка”. Праці Комісії спеціальних (допоміжних) історичних дисциплін, 252 (2006) s. 228-268; eadem, Шииталі Львова під опікою магістрату (XIV-XVIII cm.), „Лікарський збірник”. Нова серія, 10 (2002) s. 38-50.

${ }^{4} \mathrm{O}$ ile w kopii prawidłowo oddano nazwę miejscowości, chodzi o Wisznię (późniejszą Sądową Wisznię), położoną w dawnej ziemi i diecezji przemyskiej.

${ }^{5}$ Jest to zarazem pierwszy znany zapis mówiący wprost o darowiźnie na rzecz kościoła Św. Ducha (kolejny Mikołaja Bolcza miał miejsce niecałe trzy tygodnie później, zob. niżej). We wcześniejszych donacjach jako beneficjenta wskazywano szpital lwowski, który - zdaniem Mariana Bladye' i Marka Słonia - pod względem organizacyjnym i majątkowym stanowił odrębną od kościoła instytucję: Bladye', Szpital, s. 54 n.; Słoń, Szpitale lwowskie, s. 225; L. Wojciechowski, Fundacje kościelne Władystawa Opolczyka, w: Ksiąze Władysław Opolczyk. Fundator klasztoru Paulinów na Jasnej Górze w Częstochowie, red. M. Antoniewicz, J. Zbudniewek, Warszawa 2007, s. 46- 
zna stać się miała środkiem (remedium), prowadzącym do zbawienia duszy jego i całej rodziny. W korroboracji zapowiedziano uwierzytelnienie dokumentu pieczęciami: arcybiskupa i Malechowskiego ${ }^{6}$. Niestety przepadły one wraz z oryginałem aktu. Okoliczność ta istotnie utrudnia identyfikację kręgu rodzinnego darczyńcy.

Wiadomo, że w 1392 r. Malechów wykupił z rąk lwowskiego mieszczanina Piotra Broloka, Michał Łabęcki (Lambacki) ${ }^{7}$. W źródłach pojawił się po raz pierwszy w marcu 1382 r. jako świadek na dokumencie wojewody (grodzkiego) lwowskiego Mikłosza Oleksandrowicza ${ }^{8}$. Odtąd obracał się w kręgu elity ziemi ruskiej regularnie świadkując wraz z miejscowymi dygnitarzami na dokumentach: Władysława Jagiełły, starostów ruskich - Andrzeja oraz Jana z Tarnowa, a także wojewody (grodzkiego) lwowskiego Męciny z Konina9 ${ }^{9}$ W 1388 r. był obecny przy rozstrzyganiu sporu między Anną, córką Seidla Spycimira ze Lwowa a Jadwigą, wdową po Stefanie Chmielu o część Zapitowa ${ }^{10}$. Do 1397 r. Michał konsekwentnie pisał się jako Łabęcki. Dopiero w testacji trzech dokumentów Jana z Tarnowa z 1398 r. wystąpił jako Michał z Malechowa ${ }^{11}$. Doczekał się dwóch synów: Jana, świadkującego wraz z nim w 1397 r. oraz Mikołaja wzmiankowanego dwukrotnie w 1400 r. $^{12}$

W literaturze nie ma zgody co do pochodzenia i związków rodzinnych Michała Łabęckiego. Adam Szweda z pewnością mylnie utożsamiał go z wystę-

47; Szyszka, Monarsze nadania dóbr, s. 252. Zob. też Trawka, Dokument Władysława Opolczyka, s. 241, 243-245. Inaczej zdaje się sądzić Wilamowski, Strepa Jakub, s. 319, który jedynie ogólnikowo wspominając omawiany dokument, pisze, że arcybiskup ,zadbał o uposażenie szpitala Świętego Ducha, potwierdzając na jego rzecz fundacje rycerską i mieszczańską (tj. Mikołaja Bolcza - R.T.)”.

${ }^{6}$ Więcej o formularzu tego dokumentu zob.: R. Trawka, Z badań nad kancelaria arcybiskupów halicko-lwowskich. Formularz dokumentów Jakuba Strepy (w druku).

${ }^{7}$ Dokument poświadczający transakcję wystawił Jan z Tarnowa, wojewoda sandomierski i starosta ruski 27 lutego 1392 r. W testacji wystąpił m.in. arcybiskup halicki Jakub Strepa: Akta grodzkie i ziemskie z czasów Rzeczypospolitej Polskiej z Archiwum tzw. Bernardyńskiego we Lwowie (dalej: AGZ), t. I-XIX, wyd. O. Pietruski, X. Liske, A. Prochaska, Lwów 1870-1906, t. III, nr 53, s. 103104.

${ }^{8}$ Katalog dokumentów pergaminowych ze zbiorów Tomasza Niewodniczańskiego w Bitburgu (dalej: Bitburg), opr. J. Tomaszewicz, M. Zdanek, W. Bukowski, Kraków 2004, nr 17.

${ }^{9}$ AGZ II, nr 13, s. 22; nr 22, s 36; Zbiór Dokumentów Małopolskich, cz. IV, (dalej: ZDM IV), wyd. S. Kuraś i I. Sułkowska-Kuraś, Wrocław-Warszawa-Kraków 1969, nr 1075, s. 228; Bitburg, nr 23, 34; J. Sperka, Otoczenie Władysława Opolczyka w latach 1370-1401. Studium o elicie władzy $w$ relacjach $z$ monarcha, Katowice 2006, s. 281.

${ }^{10}$ ZDM IV, nr 1082, s. 234. Wprawdzie Jadwigę określono w dokumencie jako żonę (consors) Stefana, jednakże z treści dokumentu może wynikać, że w tym czasie była już wdową. Tak też: J. Szyszka, Formowanie i organizacja dóbr monarszych w ziemi lwowskiej od połowy XIV do początku XVI wieku, Kraków 2016, s. 95-96.

${ }^{11}$ Archiwum Główne Akt Dawnych w Warszawie (dalej: AGAD), perg. 7239, 7240, 7241 (dwa ostatnie dokumenty poświadczają tę samą transakcję: zamianę dóbr między Paszkiem z Jaryczowa a Wojciechem z Sulimowa, zob. niżej).

${ }^{12} \mathrm{~W}$ dokumentach tych Jan i Mikołaj zostali wprost określeni jako synowie „pana Łabęckiego”: Bitburg, nr 34 і 36; В. Розов, Українські грамоти, т. I (XIV в. і перша половина XV в.), у Київі 1928, nr 33, s. 61 = „Dodatek Tygodniowy do Gazety Lwowskiej” (dalej: DTGL), 33 (1854) s. 132. 
pującym ćwierć wieku później Michałem z Malechowa (1421-1427) ${ }^{13}$, bratem rodzonym Andrzeja (1419-1450) ${ }^{14}$ oraz bratem ciotecznym Pawła i Stanisława (Cztana) Jurkowskich herbu Grzymała (których rodzina przybyła na Ruś z ziemi sandomierskiej $)^{15}$. Z kolei Jerzy Sperka uznał Michała Łabęckiego za Awdańca. Jego ojca upatrywał w jednym z trzech braci piszących się z Łabęd koło Gliwic, którzy w 1375 r. otrzymali od Władysława Opolczyka wsie Żuków, Duszanów i Buszcze w powiecie lwowskim ${ }^{16}$. Wspomnianych wyżej synów Łabęckiego badacz ten identyfikował jako (odpowiednio) Jana Łabętę z Żukowa, występującego

${ }^{13}$ Michał Malechowski wystąpił po raz pierwszy w marcu 1421 r. jako świadek na dokumencie starosty ruskiego Iwana z Obichowa. Dwa lata później wymieniony został w testacji dokumentu starosty ruskiego Spytka z Tarnowa: Розов, Украӥнські грамоти, nr 51, s. 94 (zob.: R. Hube, Wyrok lwowski roku 1421, w: Romualda Hubego pisma, t. I-II, opr. K. Dunin, Warszawa 1905, t. II, s. 239); AGZ III, nr 95, s. 184. Natomiast wcześniejsze wzmianki o Michale, pochodzące z lat 90. XIV w., zebrane przez A. Szwedę, Jurkowscy herbu Grzymała. Przyczynek do dziejów osadnictwa polskiego na Rusi Czerwonej, w: Venerabiles, nobiles et honesti. Studia z dziejów społeczeństwa Polski średniowiecznej, Toruń 1997, s. 281-290, tu s. 283-284, odnoszą się z pewnością do Michała Łabęckiego. Pomyłka w identyfikacji wynikła zapewne z braku wiedzy autora o synach Łabęckiego (por. niżej).

${ }^{14}$ Andrzej po raz pierwszy pojawił się w źródłach 30 września 1419 r. jako odbiorca dokumentu Władysława Jagiełły, który - na jego prośby - przeniósł wsie Malechów, Żydatycze i Klekotów w powiecie lwowskim na prawo średzkie: AGZ IV, nr 47, s. 101-102 (zob. niżej). Działalność Andrzeja omówił Szweda, Jurkowscy herbu Grzymała, s. 283-286. Opierając się na ustaleniach badacza, M. Wilamowski, Familia dworska Piotra i Andrzeja Odroważów Sprowskich, wojewodów i starostów ruskich, w: Polska i jej sąsiedzi w późnym średniowieczu, red. K. Ożóg, S. Szczur, Kraków 2000, s. 302, przyjął, że Andrzej Malechowski był bratem (względnie synem) pochodzącego z ziemi sandomierskiej Michała Lambackiego, nabywcy Malechowa.

${ }^{15}$ Andrzej Malechowski dwukrotnie został określony w źródłach jako brat Pawła i Stanisława (Cztana) Jurkowskich, synów Macieja i bliżej nieznanej Oluchny: AGZ VI, nr 60, s. 89-90 (w 1464 r. jako zmarły brat Pawła Jurkowskiego) oraz AGZ XIV, nr 719 (w 1443 r. wspomniani fratres minores Andrzeja - Paszek i Cztan). Szweda, Jurkowscy herbu Grzymała, s. 283, na podstawie analizy herbów obu rodzin (rozumiejąc pojęcie „brat” sensu largo) odrzucił wcześniejszy pogląd A. Bonieckiego, Herbarz Polski (dalej: Boniecki), t. 1-16, Warszawa 1899-1916, t. 9, s. 116, który - na podstawie dużej różnicy wieku dzielącej Malechowskich od Pawła i Stanisława - twierdził, że Andrzej był synem Macieja Jurkowskiego z pierwszego małżeństwa. Zob. też: T.M. Trajdos, Dobroczyńcy mendykantów średniowiecznego Lwowa, w: Spoteczeństwo Polski średniowiecznej. Zbiór studiów, t. VII, red. S.K. Kuczyński, Warszawa 1999, s. 241. O zakresie znaczeniowym pojęcia „brat” zob.: M. Koczerska, O terminologii pokrewieństwa i powinowactwa w polskich źródłach średniowiecznych, w: Genealogia - problemy metodyczne w badaniach nad polskim społeczeństwem średniowiecznym na tle porównawczym, Toruń 1982, s. 40-41.

${ }^{16}$ Sperka, Otoczenie Władystawa Opolczyka, s. 280-281. Zob. też: idem, Z dziejów migracji rycerstwa ślaskiego na ziemie Rusi Koronnej, w: Narodziny Rzeczypospolitej. Studia z dziejów średniowiecza i czasów wczesnonowożytnych, red. W. Bukowski, T. Jurek, t. I, Kraków 2012, s. 532-533. Tym samym J. Sperka zakwestionował wcześniejsze hipotezy (J. Pilnáček, Rody starého Slezska, díl. 3, Brno 1991, s. 733; R. Sękowski, Udziat rycerstwa śląskiego w rządach i kolonizacji Rusi Czerwonej przez Wtadystawa Opolczyka - problemy genealogiczne i rozeznanie wstępne, w: Władysław Opolczyk jakiego nie znamy. Próba oceny w sześćsetlecie śmierci, red. A. PobógLenartowicz, Opole 2001, s. 131; tenże, Herbarz szlachty śląskiej, Katowice 2005, t. 4, s. 176) przypisujące - wspomnianym w 1375 r. - braciom z Łabęd herb Łabędź. 
w latach $1420-1451^{17}$ oraz Mikołaja z Żukowa, szlachcica z ziemi żydaczowskiej, który w 1436 r. przywiesił swą pieczęć z herbem Awdaniec do aktu konfederacji szlachty ruskiej ${ }^{18}$. Na słabe punkty tej teorii zwrócił ostatnio uwagę Janusz Szyszka. Wskazał m.in. na brak powiązań majątkowych Łabęckiego (którego jedyną udokumentowaną posiadłością jest Malechów) z dziedzicami Buszcza i Żukowa. Przecząc pokrewieństwu Michała z Łabętami z Żukowa połączył go natomiast z wymienionymi przed chwilą, późniejszymi posiadaczami Malechowa: Andrzejem i Michałem (widząc w nich raczej jego wnuków niż synów). Niestety, przypuszczenie jakoby Michał Łabęcki pochodził z Łabęd koło Mławy sformułowane zostało bez żadnego uzasadnienia ${ }^{19}$.

Niedostatek informacji źródłowych nie pozwala na ostateczne ustalenie genealogii Michała Łabęckiego. Dziedziczenie Malechowa przez Andrzeja i Michała (a przy tym także imię tego drugiego) wskazuje na związki rodzinne między Łabęckim a Malechowskimi ${ }^{20}$. Już jednak sama identyfikacja herbu tych ostatnich napotyka trudności. Według Jana Zamoyskiego, pieczęć, którą bracia przywiesili pod aktem homagialnym szlachty ziemi lwowskiej złożonym Władysławowi Jagielle w 1427 r., przedstawiała „konia”. Czyżby chodziło o herb Starykoń? Rozstrzygnięcie kwestii utrudnia fakt, że ani Michał, ani Andrzej nie pozosta-

${ }^{17}$ Sperka, Otoczenie Władysława Opolczyka, s. 280-281. Na temat Jana z Żukowa i jego zstępnych zob. też: Boniecki, t. 15, s. 133-134 (autor nie powiązał jednak tegoż Jana ze znanym sobie z transakcji z 1392 r. Michałem Łabęckim; nie znał też ich herbu) oraz P. Dąbkowski, Wędrówki rodzin szlacheckich. Karta z dziejów szlachty halickiej, w: Księga pamiątkowa ku czci Oswalda Balzera, t. I, Lwów 1925, s. 12.

${ }^{18}$ Jana Zamoyskiego notaty heraldyczno-sfragistyczne, wyd. F. Piekosiński, w: Studya, rozprawy i materyaty z dziedziny historyi polskiej, t. 7, Kraków 1907, nr 641, s. 70. Sperka, Otoczenie Władysława Opolczyka, s. 281, wskazał też drugą pieczęć Mikołaja z Żukowa przywieszoną do aktu homagialnego w 1427 r.: O. Halecki, Z Jana Zamoyskiego inwentarza Archiwum Koronnego materiały do dziejów Rusi i Litwy w XV w., „Archiwum Komisji Historycznej”, t. XII/1, Kraków 1912, s. 189 (tu zniekształcona nazwa de Zdurua i znajdujące się przy niej odesłanie do: Jana Zamoyskiego notaty, $\mathrm{nr}$ 770, s. 78, gdzie podano sigillum Nicolai de Zdurowa: Audank). J. Sperka nie odniósł się natomiast do tez A. Szwedy, pomijając w swoim wywodzie osoby dziedziców Malechowa: Michała i Andrzeja.

${ }^{19}$ Niepokoi oczywiście i to, że w myśl hipotezy J. Szyszki, w zbliżonym czasie, w ziemi lwowskiej mieliby się pojawić przedstawiciele dwóch rodzin wywodzących się z różnych miejscowości o identycznej a niezbyt częstej nazwie (Labędy na Śląsku i Łabędy na Mazowszu): tenże, Formowanie i organizacja dóbr, s. 128.

${ }^{20} \mathrm{Za}$ dziedziczeniem, nie zaś zakupem Malechowa przez Andrzeja i Michała może przemawiać także inna, choć niezbyt mocna przesłanka. W 1489 r., gdy Malechów znalazł się w posiadaniu lwowskiego szpitala Św. Ducha (o czym niżej), instytucja ta otrzymała najwyraźniej także dawniejsze dokumenty dotyczące uzyskanej wsi. Wynika to z faktu, że ich krótkie regesty wpisano do XVIII-wiecznego sumariusza dyplomów należących do szpitala. Najstarszym z nich jest zresztą wspomniany akt sprzedaży Malechowa Michałowi Łabęckiemu z 1392 r. W sumariuszu próżno jednak szukać świadectwa kolejnego zbycia wsi w okresie po 1392 r., a następny dokument odnoszący się do Malechowa pochodzi dopiero z lat 40. XV w.: Centralne Państwowe Archiwum Historyczne Ukrainy we Lwowie, Fond 52, op. 1, spr. 255, k. 98 nn.; odpis: AGAD, Zb. Czołowskiego, sygn. 241 , s. $64 \mathrm{nn}$. 
wił męskiego potomka ${ }^{21}$. Pierwszy wkrótce zmarł bezdzietnie, po drugim dobra, w tym Malechów, dziedziczyły córki ${ }^{22}$. W 1439 r. na dokumencie sądu ziemskiego lwowskiego świadkował jeszcze Adam, piszący się z Malechowa ${ }^{23}$ - zapewne krewny Malechowskich (brat a może syn Andrzeja). Musiał jednak umrzeć młodo, skoro później już się nie pojawił w źródłach.

Wprawdzie egzekucja zapisów dokumentu z 1399 r. dotyczących modernizacji malechowskiej karczmy przez Michała i wybierania czynszów przez prepozyta kościoła szpitalnego nie jest wprost poświadczona źródłowo, wolno się jej jednak domyślać: w 1443 r. karczma działała i przynosiła zyski²4. Kilkadziesiąt lat później Malechowem zainteresował się zarząd szpitala Św. Ducha we Lwowie. W 1489 r. sprawująca tę funkcję rada miejska nabyła wieś od Dymitra Chodorowskiego w zamian za trzy inne, należące do szpitala: Łuczany, Nahorzany zw. Piotrową Górą (Nahorynie) oraz Bołszów, położone w powiecie żydaczowskim ${ }^{25}$. Trzy lata później Malechów wypuszczono w arendę za 7 grzywien rocznie, wyjąwszy $\mathrm{z}$ transakcji czynsze w pieniądzu i wspomnianą karczmę ${ }^{26}$.

Drugi z publikowanych dokumentów wystawił 2 stycznia 1405 r. bliski współpracownik arcybiskupa Jakuba Strepy i jego imiennik - Jakub, rektor kościoła

${ }^{21}$ Jana Zamoyskiego notaty, nr 1066, s. 99 (sigillum Michaelis et Andreae fratrum de Maliechouo: equi, ut est pictus in libello Cracouiensi). Por. Halecki, Z Jana Zamoyskiego inwentarza, s. 176, 179. Szweda, Jurkowscy herbu Grzymała, s. 283, zgłosił pewne wątpliwości co do identyfikacji herbu Malechowskich ze Starym Koniem. Zwrócił bowiem uwagę, że Zamoyski - który wszak znał i odróżniał ten herb - w tym przypadku, choć podał jego nazwę, to po rysunek godła odesłał do zaginionej dzisiaj „,krakowskiej książeczki”, będącej swoistym herbarzem.

${ }^{22}$ Szweda, Jurkowscy herbu Grzymała, s. 284-287.

${ }^{23}$ Bitburg, nr 58.

${ }^{24}$ Andrzej Malechowski zabezpieczył 28 grzywien długu, który zaciągnął u Jana Cyrana z Siemionowej Woli, intromisją w karczmę, sadzawkę i młyn w Malechowie: AGZ XIV, nr 853, s. 109.

${ }^{25}$ AGZ VII, nr 92, s. 167-169; Skoczek, Ze studiów, s. 98 [352]; Słoń, Szpitale lwowskie, s. 224. Zob. też: Słownik geograficzny Królestwa Polskiego i innych krajów słowiańskich (dalej: SGKP), red. F. Sulimierski, B. Chlebowski, W. Walewski, t. I-XV, Warszawa 1880-1902, t. VI, s. 7, 879 (Nahorynie, późn. część wsi Oryszkowce [Orzeszkowice]); S. Tylus, Dwa dokumenty z 1521 roku (Malechów i Rodatycze - archidiecezja lwowska), w: Ku prawdzie w miłości. Księga pamiatkowa poświęcona Księdzu Biskupowi Profesorowi Janowi Śrutwie, red. S. Koczwara, Lublin 2002, s. 95-101, tu s. 95 (tu także krótka informacja o początkach parafii w Malechowie). Dokonaną zamianę rajcy tłumaczyli znaczną odległością wymienionych wsi od szpitala i wynikającymi stąd trudnościami w zarządzaniu nimi. Na zamianę tę przystał - a niewykluczone, że ją zainicjował - Dymitr. Wspomniane dobra należały bowiem wcześniej do rodziny Chodorowskich. Szpitalowi Św. Ducha zapisał je w testamencie w 1457 r. Jan Chodorowski z Brzozdowców (AGZ V, nr 152, s. 200-202; wydawca - opierając się na pracy K. Raspa - identyfikował wieś Bolszow z miasteczkiem Bołszowce w pobliżu Halicza, w przedwojennym powiecie rohatyńskim; por. SGKP, t. V, s. 794). Zawarta trzydzieści lat później umowa ze szpitalem przewidywała, że Dymitr wykupi najpierw Malechów z rąk Jana Karawy, a następnie dokona wspomnianej zamiany. 15 kwietnia 1489 r. zatwierdził ją Kazimierz Jagiellończyk, włączając na powrót wsie Chodorowskiego do prawa ziemskiego, wyjmując zaś spod świeckiej jurysdykcji i świadczeń na rzecz króla Malechów.

${ }^{26}$ SGKP, t. VI, s. 7. 
Św. Ducha od 1395 r. ${ }^{27}$, a od 1401 r. także oficjał halicki ${ }^{28}$. Nadał on wówczas - położone koło monasteru w Srokach, przy drodze wiodącej do Lwowa - łąki wraz z rosnącym pośród nich lasem i dąbrową, Stanisławowi zwanemu też Zelko (Żelko), wicesołtysowi z pobliskiej wsi Prusy ${ }^{29}$. Jak wówczas obliczono, przeznaczony pod uprawę i karczunek obszar obejmował około pół łana. Kontrakt z sołtysem przewidywał okres wolnizny, wynoszący z lasu -20 , z dąbrowy -6 , a z pól i łąk - 3 lata. Po jego upływie Stanisław i jego potomkowie mieli płacić czynsz na św. Marcina każdorazowemu rektorowi kościoła Św. Ducha w wysokości 15 szerokich groszy (czeskich). Dokument spisany został zapewne w kancelarii arcybiskupa Jakuba Strepy przez jednego z jej pisarzy. Wskazują na to pewne podobieństwa formularzowe do kilku dyplomów arcybiskupa z 1399 r., przede wszystkim charakterystyczny zapis miejsca jego wystawienia w języku polskim ${ }^{30}$. Dokumentowi nadano uroczystą formę, wprowadzając do niego arengę typu me-

${ }^{27}$ Jakub jako rektor kościoła szpitalnego wystąpił po raz pierwszy 5 czerwca 1395 r. w testacji dokumentu własnego notariusza publicznego Wawrzyńca syna Dydka z Sandomierza, który poświadczył ugodę zawartą między arcybiskupem halickim Jakubem Strepą, a mieszczanami lwowskimi w sprawie spornego domu położonego przy lwowskim rynku. Dwa lata później (22 kwietnia 1397 r.) Jakub był świadkiem na dokumencie wojewody sandomierskiego i starosty ruskiego Jana z Tarnowa, który w imieniu króla zawarł kontrakt na sołectwo w królewskiej wsi Sokolniki w ziemi lwowskiej. Kolejny raz prepozyt świadkował 17 lipca 1400 r. na dokumencie arcybiskupa halickiego dla kościoła w Wyżnianach, fundowanego przez Jana Klusa z Wyżnian i jego żonę Małgorzatę: DTGL 21-22 (1854), s. 84, 88 = AGZ III, nr 58, s. 108-110; Biblioteka XX. Czartoryskich w Krakowie, perg. 249; DTGL 25-27 (1852), s. 100, 104, 108 = Tylus, Fundacje kościołów parafialnych, Dokument nr 47, s. 225-226, przyp. 7; Trawka, Dokument Władysława Opolczyka, s. 242, 245.

${ }_{28}$ Świadkował wówczas na testamencie Jakuba Strepy: J. Skrobiszewski, Vitae archiepiscoporum Haliciensium et Leopoliensium, Leopoli 1628, H 3 nn. = BN, rkps II 12406, s. 42 [25v]. W dotychczasowej literaturze jako początek sprawowania urzędu oficjała przez Jakuba podawano rok 1405: AGZ II, nr 68; J. Krętosz, Organizacja archidiecezji lwowskiej obrządku łacińskiego od XV wieku do 1772 r., Lublin 1986, s. 90; Tylus, Fundacje kościołów parafialnych, Dokument nr 47, s. 225-226, przyp. 7. Ostatni raz Jakub wzmiankowany jest 14 października 1407 r.: AGZ IV, nr 15, s. 57. Zob. też: tamże, nr 13, s. 32, 36-38, nr 14, s. 43.

${ }^{29}$ Jest to jedyne znane wystąpienie Stanisława alias Zelka (Żelka), wicesołtysa w Prusach. O innych osobach noszących imię Żelko (Żelek) zob.: Stownik staropolskich nazw osobowych, t. VI-VII, red. W. Taszycki, Wrocław-Warszawa-Kraków-Gdańsk-Łódź 1981-1987, t. VI/3, s. 360 i t. VII/3 Suplement, s. 310.

${ }^{30}$ Nazwę „Lwów” w polskim brzmieniu wprowadzono do datacji trzech dokumentów Jakuba Strepy z 1399 r.: dwóch dla rektora szpitala Św. Ducha, a jednego dla rektora kościoła w Buszczu: AGZ III, nr 68, s. 133-134; W. Abraham, Jakób Strepa arcybiskup halicki 1391-1409, Kraków 1908, Dokument nr VII, s. 104-105; L. Finkel, Sprawozdanie z wycieczki konserwatorskiej [w spisie treści jest tytuł: Wycieczka do Krasnopuszczy], ,Teka Konserwatorska Koła C.K. Konserwatorów Starożytnych Pomników Galicyi Wschodniej” 2, Lwów 1900, s. 93 = Tylus, Fundacje kościołów parafialnych, Dokument nr 6, s. 111-113. O przyczynach użycia polskiej nazwy zob.: Abraham, Jakób Strepa, s. 59; Trajdos, Kościót katolicki na ziemiach ruskich Korony i Litwy za panowania Wtadystawa II Jagietty (1386-1434), t. 1, Wrocław 1983, s. 228; M. Wilamowski, Strepa (Strzemię) Jakub, s. 321. Zwraca też uwagę m.in. podobieństwo stylistyki promulgacji omawianego dokumentu ze wskazanymi w tym przypisie dyplomami Jakuba Strepy z 1399 r. Zob. Trawka, $Z$ badań nad kancelarią. 
moria - oblivio ${ }^{31}$. Zwięźle wyrażono natomiast motyw nadania: jego celem miało być powiększenie dochodów kościoła Św. Ducha.

Nieznane są okoliczności, w jakich owo pół łana znalazło się w dyspozycji prepozyta szpitalnego. Wątpić należy, by mogło pochodzić z nadania monarchy, chociaż w tym czasie i Sroki, i sąsiednie Prusy stanowiły własność królewską. Może więc ziemia należała pierwotnie do przylegającego monasteru (bazyliańskiego?). Informację o klasztorze w Srokach potwierdza dokument Władysława Jagiełły z $1421 \mathrm{r}^{32} \mathrm{Z}$ nagłówka we wspomnianym kopiariuszu wynika, że grunt nadany Stanisławowi (pratum Nadzieiowka) w XVI w. znajdował się już w granicach sąsiedniej wsi królewskiej Prusy. Uprawiany przez niejakiego Grzegorza Lisa przynosił wówczas prepozytowi szpitala 36 groszy rocznego zysku.

Dokument Jakuba nie jest jedynym świadectwem jego starań o wzrost dochodowości prebendy szpitalnej. Jeszcze w 1399 r. nabył on dla lwowskiego kościoła Św. Ducha działkę położoną w bezpośrednim sąsiedztwie szpitala, otrzymując jednocześnie od sprzedającego - mieszczanina lwowskiego Mikołaja Bolcza darowiznę w postaci połowy ustalonej ceny zakupu, tj. 10 grzywien ruskich ${ }^{33}$. W 1405 r. zatroszczył się o przywilej lokacyjny dla swych wsi Żydatycz i Hodowic: w październiku tego roku Władysław Jagiełło przeniósł je na prawo magdeburskie $^{34}$. W swych zabiegach o dofinansowanie prepozytury Jakub otrzymał realne wsparcie ze strony arcybiskupa halickiego Jakuba Strepy ${ }^{35}$.

$$
* * *
$$

Edycję opracowano zgodnie z wytycznymi instrukcji wydawniczej Adama Wolffa, uwzględniając uwagi zamieszczone we Wstępie do tomu VI Kodeksu Dyplomatycznego Wielkopolski ${ }^{36}$.

${ }^{31}$ Arenga ta znana jest także z późniejszego dokumentu braci Przecława i Mikołaja z Bujowic, wystawionego 23 czerwca 1408 r. w Przemyślu, a dotyczącego uposażenia fundowanego kościoła parafialnego w tej miejscowości: AGZ VI, nr 10, s. 15.

${ }^{32}$ Król nadał wówczas tę wieś cum Monasterio et piscina Comorew seu Kruków Grzegorzowi Ormianinowi z Laszek: S. Barącz, Żywoty sławnych Ormian w Polsce, Lwów 1856, s. 134-135. O samym nadaniu Srok zob. Szyszka, Formowanie i organizacja dóbr, s. 118-119.

${ }^{33}$ Sprzedaż i darowiznę potwierdził arcybiskup Jakub Strepa: AGZ III, nr 68, s. 133-134. Zob. też: Słoń, Szpitale lwowskie, s. 223, 225.

${ }^{34}$ AGZ II, nr 33, s. 53-55. Żydatycze - jak przypuszcza J. Szyszka - weszły w skład prebendy szpitalnej ok. 1399 r. (po 1405 r. a przed 1419 r. w drodze zamiany lub sprzedaży znalazły się w rękach Andrzeja z Malechowa, zob. wyżej), natomiast Hodowica należała wprawdzie do prebendy św. Jana Chrzciciela, ale jak wynika z dokumentu była w dyspozycji Jakuba, rektora kościoła Św. Ducha: idem, Monarsze nadania dóbr ziemskich, s. 252-253.

${ }^{35}$ Jakub Strepa w 1399 r. przekazał kościołowi Św. Ducha dziesięciny ze wsi Prusy: AGAD, perg. 6077 = Abraham, Jakób Strepa, Dokument nr VII, s. 104-105. Zob. też m.in.: Trajdos, Kościót katolicki, s. 253; Szyszka, Monarsze nadania dóbr, s. 252.

${ }^{36}$ Kodeks Dyplomatyczny Wielkopolski, t. VI, wyd. i opr. A. Gąsiorowski, H. Kowalewicz, Warszawa-Poznań 1982; A. Wolff, Projekt instrukcji wydawniczej dla pisanych źródet historycznych do połowy XVI wieku, „Studia Źródłoznawcze”, 1 (1957) s. 155-184. 


\section{DOKUMENTY}

I

(Sadowa) Wisznia, 9 IV 1399 r.

Arcybiskup Jakub Strepa poświadcza, że szlachetny Michat z Malechowa zapisat rektorowi kościoła Św. Ducha we Lwowie czynsz roczny z karczmy w Malechowie.

Oryginal: nieznany

Kopia: Biblioteka Naukowa im. W. Stefanyka Narodowej Akademii Nauk Ukrainy we Lwowie, Fond 5, op. 1, spr. 2155, k. 10v-11r z nagłówkiem: Litere super censum unius sexagene in Malechow, nad którym podano rok: anno 1399.

In nomine Domini amen. Ad perpetuam rei memoriam. Jacobus Dei gracia archiepiscopus sacrosancte ecclesie Haliciensis ${ }^{1}$ ad universorum noticiam per presens scriptum volumus devenire, quod nobilis vir dominus Michael de Malechow ${ }^{2}$ zelo pye devocionis accensus, in nostra constitutus presencia, sanus mente pa-

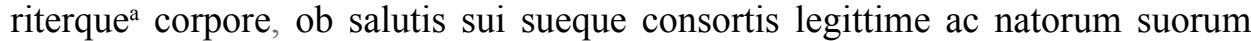
necnon progenitorum salubre remedium, ipsarum videlicet animarum ${ }^{\mathrm{b}}$, unam sexagenam grossorum monete et pagamenti usualium in territorio Russie decurrentium in taberna sua in eadem Malechow sitta district(us) Lemburgens(is) pro iugi censu reddituque singulis annis ad festum sancti Martini confessoris integraliter persolven(dam) honorabili viro domino Jacobo rectori ecclesie hospitalis Sancti Spiritus Lamburgensis ${ }^{3}$ suisque successoribus in eadem pro tempore presidentibus dedit, assignavit et in perpetuum duratur(um) incorporavit, residuum vero censum eiusdem taberne pro se suisque posteris reservan(do), hac tamen condicione specialiter etiam expressa, quod idem Michael prenominatus suique successore $^{\mathrm{c}}$ ipsam tabernam pretuitam reparare, emendare, necnon tabernaliter constituere debebit ac debebunt. Ne quispiam scrupulus [11 r impedimenti vel, quod absit, occasione sinistra in exactione eiusdem sexagene iugiter ut prefertur assignate ipsi domino Jacobo prefato et suis posteris in eadem ecclesia pro rectore legittimo ${ }^{\mathrm{d}}$ existentibus oriatur. Harum quibus sigillum nostrum unacum eiusdem Michaelis sepefati sigillo presentibus est appensum testimonio literarum. Datum et actum in Vissnya ${ }^{4}$ feria quarta post Conductum Pasce sub anno Domini Millesimo tricentesimo

I ${ }^{\mathrm{a}}$ wyraz nadpisany nad przekreśleniem kop. ${ }^{\mathrm{b}}$ następuje wyraz częściowo przekreślony suarum kop. ${ }^{\mathrm{c}}$ nastepuje wyraz przekreślony prefatam kop. ${ }^{\mathrm{d}}$ wyraz nadpisany kop.

${ }^{1}$ Jakub Strepa (ok. 1340-1409), gwardian klasztoru franciszkanów we Lwowie, wikariusz Stowarzyszenia Braci Pielgrzymujacych dla Chrystusa na Ruś, arcybiskup halicki (prekonizowany 27 czerwca 1391 r., konsekrowany 28 października 1392 r.), błogosławiony: Abraham, Jakób Strepa arcybiskup halicki 1391-1409, Kraków 1908; Wilamowski, Strepa (Strzemię) Jakub, w: PSB, t. 44, Kraków 2006-2007, s. 318-324.

${ }^{2}$ Zob. tekst główny. Malechów (ukr. Малехів), wieś w powiecie lwowskim, ok. 6 km na NE od Lwowa: SGKP, t. VI, s. 6-7.

${ }^{3} J a k u b$, rektor kościoła szpitalnego Św. Ducha we Lwowie od 1395 r. i oficjat halicki od 1401 r., zob. przyp. 26 i 27 w tekście głównym.

${ }^{4}$ Sadowa Wisznia (ukr. Судова Вишня), miasto położone ok. $17 \mathrm{~km}$ na E od Mościsk: SGKP, t. X, s. 361, zob. przyp. 4 w tekście głównym. 
nonagesimo nono. Presentibus nobilibus dominis Nicolao Mzurovsky ${ }^{5}$, Joanne de Visznyany Kluss ${ }^{6}$, Menczyna voyevoda Lemburgensi ${ }^{7}$, Nicolao Juskonis de Volkow ${ }^{8}$,

${ }^{5}$ Mikołaj Mzurowski h. Amadej, z Mzurowa (koło Lelowa) i Rudołowic (w ziemi przemyskiej); występuje w l. 1390-1400; może tożsamy z Mikołajem ,, dicto Mszurowski”, świadkiem na dokumencie kasztelana sandomierskiego Jana z Tarnowa z 1378 r.; fundator kościoła $w$ Rudolowicach i donator kościoła w Strzelczyskach: AGAD, perg. 7247 (1400 r.); Codex Diplomaticus Poloniae, t. III, ed. J. Bartoszewicz, Varsaviae 1858, $n$ r 160, s. 320; AGZ VI, $n$ r 2, s. 4; ZDM IV, nr 1132, s. 302-303, oraz $n r$ 1102, s. 266, $n r$ 1107, s. 271, $n r$ 1111, s. 277, $n r$ 1113, s. 280; С.С. Пашин, Перемылильская иляхта второй половины XIV - начала XVI века. Историко-генеалогическое иследование, Тюмен 2001, s. 52-53; J. Kus, Manowie jarosławscy. Z zagadnień stosunków lennych na Rusi Czerwonej (XIV-XVI w.), „,Przemyskie Zapiski Historyczne”, 3 (1985) s. 19-35, tu s. 28-30, 33, w oparciu o informacje A. Jabłonowskiego, Polska XVI wieku pod względem geograficzno-statystycznym, t. VII/2: Ziemie ruskie. Ruś Czerwona, Warszawa 1903, s. 330, przypisuje Mzurowskim herb Nieczuja. Tak tė̇: G. Klebowicz, Organizacja parafialna diecezji przemyskiej obrzadku łacińskiego w XIV-XVI wieku, Lublin 2013, s. 290-292. Przynależność herbowa (rodowa) Mzurowskich określa pieczęć oraz zeznanie przed sadem z 1417 r. Jana Mzurowskiego, syna Mikołaja: Notaty Jana Zamoyskiego, $n r$ 340; Z ksiag rękopiśmiennych dotąd nie użytych, głównie zaś z ksiag dawnych sąowych ziemskich i grodzkich ziemi krakowskiej, wyd. A.Z. Helcel, w: Starodawne Prawa Polskiego Pomniki, t. II (dalej: SPPP II), Kraków 1870, nr 1497, s. 216; W. Semkowicz, O pochodzeniu i rozsiedleniu rodu Amadejów w Polsce, ,, Miesięcznik Heraldyczny”, 5 (1912) 9-10, s. 139-143.

${ }^{6}$ Jan Klus z Wyżian h. Szreniawa, występuje w l. 1393-1418, od 1393 r. żonaty z Matgorzata, córka Chodka Łojowicza z Wyżnian; zdaniem Jerzego Sperki tożsamy z Jaśkiem Klusem występujacym w l. 1371-1378; fundator kościoła w Wyznianach: Biblioteka XX. Czartoryskich w Krakowie, perg. 249; AGAD, perg. 7244, 7249; AGZ IV, nr 39; Boniecki, t. 10, s. 153; Tylus, Fundacje kościotów parafialnych, s. 66-67, Dokument $n r$ 9, s. 122; $n r$ 47-48, s. 223-228; Sperka, Otoczenie Władysława Opolczyka, s. 212-213; tenże, Zarys migracji rycerstwa śląskiego na ziemie Rusi Koronnej w okresie panowania Władystawa Jagietly, w: Княжа доба: історія $i$ культура, red. Л. Войтович, вип. 5, Львів 2011, s. 221-222; Szyszka, Formowanie i organizacja dóbr, wg indeksu.

${ }^{7}$ Męcina, syn Prędoty z Konina h. Rawa, burgrabia zamku niższego we Lwowie (tytułowany wojewoda lwowskim) w l. 1394-1400; fundator kościoła w Witowskiej Woli (późn. Konińskiej): Biblioteka XX. Czartoryskich w Krakowie, perg. 249; AGAD, perg. 7242 (1400 r.); AGZ III, nr 57, s. 107; Bitburg, $n r$ 34, 36; K. Maleczyński, Urzędnicy grodzcy i ziemscy lwowscy w latach 1352-1783, Lwów 1938, s. 42, 54; J. Wroniszewski, Ród Rawiczów. Warszowice i Grotowice, Toruń 1992, s. 51 52 i tab. III; A. Sochacka, Własność ziemska $w$ województwie lubelskim $w$ średniowieczu, Lublin 1987, s. 24, 76; taż, Przed nadaniem prawa miejskiego, w: Dzieje Końskowoli, red. R. Szczygiel, Lublin 1988, s. 26-27; taż, Ziemia lubelska pomostem w migracji szlachty polskiej na Ruś w późnym średniowieczu, w: taż, Regimen. Dominium. Societas nobilium. Z dziejów gospodarki, administracji i polityki w Lubelskiem w średniowieczu, Lublin 2014, s. 234.

${ }^{8}$ Mikolaj z Wolkowa, syn Joszka znanego z testacji dokumentu starosty ruskiego Gniewosza z Dalewic z 1393 r. Nie jest pewne, czy należy go utożsamić z wystepujacym w l. 20. XV w. Mikołajem, czy też w tym ostatnim widzieć już jego syna, brata Jana. Pisat się z Wotkowa (ukr. Вовків) położonego $w$ ziemi lwowskiej, $14 \mathrm{~km}$ na SE od Lwowa: AGZ III, $\mathrm{nr}$ 56, s. 107; AGZ IV, $\mathrm{nr}$ 65, s. 122; AGZ XIV (wg indeksu); SGKP, t. XIII, s. 871. Por. Szyszka, Formowanie i organizacja dóbr, s. 118 . 
Nicolao de Kulikow ${ }^{9}$, Kostkone Szelwowowicz ${ }^{10}$ heredibus et aliis quampluribus fidedignis.

Lwów, 2 I $1405 r$.

Jakub, oficjat halicki i rektor kościoła Św. Ducha we Lwowie nadaje Stanistawowi alias Żelce, wicesoltysowi w Prusach taki, las i dąbrowę na wykarczowanie i pod uprawę, z których po okresie wolnizny on i jego następcy ptacić będa czynsz rektorowi wspomnianego kościoła.

\section{Oryginal: nieznany}

Kopia: Biblioteka Naukowa im. W. Stefanyka Narodowej Akademii Nauk Ukrainy we Lwowie, Fond 5, op. 1, spr. 2155, k. 9v-10r z nagłówkiem: Donacio prati Nadzieiowka, quod nunc extirpatum est iam in Prussy, in quo Gregorius Lyss sedet et solvit de eo grossos 36, nad którym podano rok: anno 1405 .

In nomine Domini amen. Cum omnium memoria potius divinitatis sit, quam humanitatis, condicionis humane fragilitas remedium sibi quesivit artificio, in quo fabrice naturalis vigor summi deficit opificis voluntate. Ne igitur gesta hominum, que in tempore fiunt, simul cum lapsu coram nobis temporis ab humano recordio evanescant $t^{\mathrm{b}}$, dignum est, ut fidedignorum testium amminiculo et literarum ministerio perhennentur. Proinde nos Jacobus officialis ${ }^{\mathfrak{c}}$ Haliciensis ac rector ecclesie Sancti Spiritus in Lemburga ${ }^{1}$ ad universorum noticiam presencium et futurorum per hec scripta volumus devenire, quod cupientes, ut regiminis nostri ecclesia Sancti Spiritus augeretur in suis redditibus et proventibus ampliora valeat suscipere incrementa, prata circa monasterium, q(uo)d wl(garite)r Nadzieyovycze ${ }^{2}$ [nuncupatur $\left.{ }^{\mathrm{d}}\right]$, circa antiquam piscinam et iuxta viam, que tendit in Lemburgam

${ }^{9}$ Mikołaj z Kulikowa h. Drzewica, wystepuje w l. 1393-1411; fundator kościoła w Kulikowie $i$ kaplicy św. Michała we Lwowie. Przynależność rodowa (herbowa) określa pieczęć jego syna Jana Kulikowskiego: AGAD perg. 7239, 7240, 7244, 7247; Bitburg, $n r 31$ (28 marca 1393); $n r$ 39; 40; AGZ I, nr 10, s. 13; AGZ X, nr 29 i 39; Jana Zamoyskiego notaty, nr 181, s. 31; Abraham, Jakób Strepa, Dokument nr VI; Boniecki, t. 13, s. 153; Tylus, Fundacje kościotów parafialnych, Dokument nr 14, s. 134, nr 27, s. 166. Kulików (zw. Boszczem, ukr. Куликів), w ziemi lwowskiej, 16 km na N od Lwowa: SGKP, t. IV, s. 863-864. Szyszka, Formowanie i organizacja dóbr, s. 80, uważa Kulikowskich za potomków Stanisława Drzewięty z Borku.

${ }^{10}$ Kostek Szetwowicz (forma Szelwowowicz jest prawdopodobnie wynikiem błędu kopisty), wystepuje w l. 1396-1397 jako świadek na dokumentach: Gniewosza z Dalewic, starosty halickiego, trembowelskiego i zydaczowskiego, Jana z Tarnowa, wojewody sandomierskiego i starosty ruskiego oraz Męciny z Konina, wojewody (burgrabiego) lwowskiego: Bitburg, nr 32, 33, 34.

II ${ }^{a}$ quesuivit kop. ${ }^{\mathrm{b}}$ evanescunt kop. $\quad{ }^{\mathrm{c}}$ offitialis kop. $\quad{ }^{\mathrm{d}}$ brak kop.; kontekst wskazuje na opuszczenie stowa nuncupatur lub innego czasownika o podobnym znaczeniu

${ }^{1}$ Por. dokument nr I, przyp. 3.

${ }^{2}$ Nadziejowice, skądinąd nieznane. 
et circa silvam, que tendit ex altera parte circa nemora eundo ad molendinum in graniciis ville dicte $\mathrm{Sroki}^{3}$, illa omnia prata, in medio dictorum pratorum silvam et mericam, que simul possunt se extendi ad medium mansum, provido Stanislao alias Zelkoni vicesculteto de villa dicta [10r] Prussi ${ }^{4}$ et suis legittimis posteris ad colendum et ad locandum de novo in locis silvestrinis et de novo extirpan$\mathrm{d}(\mathrm{um})$ agros et prata perpetuis temporibus dedimus et contulimus cum effectu. Quiquidem Zelko in silva viginti annorum, in mericis sex annorum, in puris agris et pratis trium annorum libertatem habebit cum omni facultate. Elapsa vero iam dicta libertate prefatus Zelko et sui legittimi posteri pro censu singulis annis in festo sancti Martini confessoris atque pontificis nobis aut nostro successori legittimo ecclesie Sancti Spiritus in Lemburga quindecim grossos latos tenebitur solvere aut Bohemicales. Ad quorum evidentiam sigillum nostrum est appensum. Datum in Lwow alias in Lemburg in crastino Circumcisionis Domini nostri Ihesu Cristi anno Domini millesimo quadringentesimo quinto. Presentibus $\left[\ldots . . .{ }^{\mathrm{e}}\right]$ viris dominis Adalberto de Sulymow ${ }^{5}$, Stanislao de Pieczichwosti ${ }^{6}$, Przybyslao dicto

II ${ }^{\mathrm{e}}$ luka kop.

${ }^{3}$ Sroki Lwowskie (ukr. Сороки-Львівські), wieś nad rzeka Pettwia w ziemi lwowskiej, 8 km na NE od Lwowa: SGKP, t. XI, s. 166-167.

${ }^{4}$ Stanisław alias Zelko (Żelko, Żelek), wicesoltys w Prusach, bliżej nieznany. Prusy (dziś ukr. Ямniль), wieś położona nad rz. Pettwia w ziemi lwowskiej, ok. 10,5 km na NE od Lwowa, w bezpośrednim sasiedztwie Srok: SGKP, t. IX, s. 85; Szyszka, Formowanie i organizacja dóbr, s. 442.

${ }^{5}$ Wojciech z Sulimowa, w 1398 r. pisat się też z Krzywic (Krzywczy). Zamienit wówczas z Paszkiem z Jaryczowa swa wieś Dziedziłów na Odnów i Doroszów: AGAD perg. 7240, 7241; Szyszka, Formowanie i organizacja dóbr, s. 119. Sulimów (ukr. Сулимiв), wieś w ziemi lwowskiej, $20 \mathrm{~km}$ na NW od Żółkwi i $9 \mathrm{~km}$ na SE od Kulikowa. W tym czasie własność w Sulimowie byta zapewne podzielona (zob. niżej). Niewykluczone, że Wojciech byt ojcem wystepujacych w 1421 r. braci niedzielnych: Wojciecha zwanego Ślizień z Sulimowa (tytulującego się $w$ tym roku bytym burgrabia zamku lwowskiego) i Stanisława h. Chorabała (Ślizień, Ślidzień): Kamaлoz пергаментних документів Центрального Державного Историчного Архіву ҮРСР у Львові 1233-1799, орг. О.А. Купчинский, Э.И. Ружиикий, Киів 1972, nr 67, s. 55; AGZ IV, nr 56, 57; M. Haisig, Sfragistyka szlachecka doby średniowiecza w świetle archiwaliów lwowskich (z 9 tablicami pieczęci), Lwów 1938, s. 50, nr 127; Maleczyński, Urzędnicy grodzcy, s. 54 (autor dopuszcza możliwość, że Wojciech Ślizień byt tożsamy z wystęujacym w 1435 r. pisarzem grodzkim lwowskim); J. Szymański, Herbarz średniowiecznego rycerstwa polskiego, Warszawa 1993, s. 98.

${ }^{6}$ Stanisław z Pieczychwostów, skądinąd nieznany. W 1427 r. poświadczony jest Pawet z Pieczychwostów h. Gozdawa (prawdopodobnie syn wspomnianego Stanisława), brat stryjeczny Stanisława Krzywieckiego z Krzywczyc w ziemi lwowskiej (5 km na NE od Lwowa). Pawet zmart przed 12 kwietnia 1454 r. Z matzeństwa z Katarzyna, siostra Włodka z Koczarowa pozostawit synów: Jana i Pawła oraz córkę Katarzynę: Jana Zamoyskiego notaty, nr 1105, s. 101; Materiaty do historyi prawa i heraldyki polskiej, wyd. B. Ulanowski, AKH III, Kraków 1886, nr 243, s. 369; AGZ II, nr 60; AGZ VII, nr 55; AGZ X, nr 190; AGZ XIV i XV - wg indeksu; Boniecki, t. 13, s. 33; J. Fijatek, Tarlowie. Znamienitego rodu początki i świetność, „Przegląd Historyczny”, 8 (1909) s. 301-302; Szyszka, Formowanie i organizacja dóbr, s. 96-97, 101, 113, 336, domyśla się w Stanisławie z Krzywczyc potomka występującego w l. 1384-1390 Paszka z Krzywczyc. Być może więc ów Paszek z Krzywczyc byt bratem Stanisława z Pieczchwostów. Pieczychwosty (ukr. Печихвости) wieś w ziemi lwowskiej, 25 km na SE od Żółkwi, w 1376 r. nadana przez Władysława Opolczyka Ormianinowi Malianowi Szachamowiczowi: SGKP, t. VIII, s. 74; Sperka, Otoczenie Władystawa Opolczyka, s. 88. 
Chemelone $^{7}$, Petro dicto Folmar de Myklussow ${ }^{8}$, Mathia de Latossyn ${ }^{9}$, Clemente concive de Pylzno ${ }^{10}$ et aliis quamplurimis fidedignis.

Słowa kluczowe: arcybiskup halicki Jakub Strepa - oficjał halicki Jakub - szpital i kościół Św. Ducha we Lwowie - szlachta województwa ruskiego w średniowieczu

\section{BIBLIOGRAFIA}

\section{Źródła rękopiśmienne}

Archiwum Główne Akt Dawnych w Warszawie (AGAD)

Dokumenty pergaminowe sygn. 6077, 7239, 7240, 7241, 7242, 7244, 7247, 7249

Zb. Czołowskiego, sygn. 241

Biblioteka Narodowa w Warszawie (BN)

Rkps II 12406, Materiały K. Chodkiewicza, s. 42 [k. 25v]

Biblioteka XX. Czartoryskich w Krakowie

Dokumenty pergaminowe sygn. 249

Centralne Państwowe Archiwum Historyczne Ukrainy we Lwowie

Fond 52, op. 1, spr. 255

Naukowa Biblioteka im. W. Stefanyka Narodowej Akademii Nauk Ukrainy we Lwowie:

Fond 5, op. 1, spr. 2155

\section{Źródła drukowane}

Akta grodzkie i ziemskie z czasów Rzeczypospolitej Polskiej z Archiwum tzw. Bernardyńskiego we Lwowie, t. I-XIX, wyd. O. Pietruski, X. Liske, A. Prochaska, Lwów 1870-1906.

${ }^{7}$ Przybystaw (Przybko) zwany Chmiel z Sulimowa h. Nieczuja; w 1403 r. naganiony przez Guntera Borschnitza bronit swego pochodzenia ,de clenodio crucis et Ostrwa fratrum suorum, de proclamatione Neczuya". Pisat się z Sulimowa (zob. wyżej).W zapisce określono go jako pochodzacego „,de terra Russie”: SPPP II, nr 973, s. 146; SGKP, t. XI, s. 571. Przypuszczalnie byt synem wspomnianego w $1388 \mathrm{r}$. Stefana Chmiela z Drohoszowa (Doroszów w ziemi lwowskiej) i jego żony Jadwigi, zapewne tożsamej z mieszczka lwowskg o tym samym imieniu, występujaca w $1385 \mathrm{r}$. jako „relicta Chemek”, która wraz z bratem Miczkiem zastawiła wówczas swa wieś Sulimów Marcinowi z Nowego Miasta, obywatelowi Lwowa: Najstarsza ksiega miejska 1382-1389, wyd. A. Czołowski, Lwów 1892, nr 269; ZDM IV, nr 1082, s. 233-234.

8 Piotr Folmar z Miklaszowa, tawnik lwowski w 1384 r., rajca lwowski w l. 1399-1410: M. Kapral, Urzędnicy miasta Lwowa w XIII-XVIII wieku, Toruń 2008 (Spisy urzędników miejskich z obszaru dawnej Rzeczypospolitej, Śląska i Pomorza Zachodniego, t. VII: Ziemie Ruskie, z. 1: Lwów), nr 359, s. 194, oraz nr 30, s. 46-50. Mikłaszów (ukr. Myklasziv), wieś w ziemi lwowskiej; 14 km na E od Lwowa: SGKP, t. VI, s. 396-397.

${ }^{9}$ Maciej z Latoszyna (wieś w powiecie pilzneńskim województwa sandomierskiego), mieszczanin lwowski, bliżej nieznany.

${ }^{10}$ Klemens z Pilzna, bliżej nieznany mieszczanin lwowski. 
Codex Diplomaticus Poloniae, t. III, ed. J. Bartoszewicz, Varsaviae 1858.

„Dodatek Tygodniowy do Gazety Lwowskiej”, 25-27 (1852), s. 100, 104, 108; 33 (1854), s. 132.

Finkel Ludwik, Sprawozdanie z wycieczki konserwatorskiej [w spisie treści jest tytuł: Wycieczka do Krasnopuszczy], „Teka Konserwatorska Koła C.K. Konserwatorów Starożytnych Pomników Galicyi Wschodniej” 2, Lwów 1900, s. 93.

Halecki Oskar, Z Jana Zamoyskiego inwentarza Archiwum Koronnego materiały do dziejów Rusi i Litwy w XV w., ,Archiwum Komisji Historycznej”, t. XII/1, Kraków 1912

Hube Romuald, Wyrok lwowski roku 1421, w: Romualda Hubego pisma, t. I-II, opr. K. Dunin, Warszawa 1905.

Jabłonowski Aleksander, Polska XVI wieku pod względem geograficzno-statystycznym, t. VII/2: Ziemie ruskie. Ruś Czerwona, Warszawa 1903.

Jana Zamoyskiego notaty heraldyczno-sfragistyczne, wyd. F. Piekosiński, w: Studya, rozprawy i materyały z dziedziny historyi polskiej, t. 7, Kraków 1907.

Kodeks Dyplomatyczny Wielkopolski, t. VI, wyd. i opr. A. Gąsiorowski, H. Kowalewicz, Warszawa-Poznań 1982

Materiały do historyi prawa i heraldyki polskiej, wyd. B. Ulanowski, „Archiwum Komisji Historycznej", t. III, Kraków 1886.

Najstarsza księga miejska 1382-1389, wyd. A. Czołowski, Lwów 1892.

Розов Володимир, Українські грамоти, т. I (XIV в. і перша половина XV в.), у Київі 1928.

Skrobiszewski Jakub, Vitae archiepiscoporum Haliciensium et Leopoliensium, Leopoli 1628.

Z ksiąg rękopiśmiennych dotąd nie użytych, głównie zaś z ksiąg dawnych sądowych ziemskich i grodzkich ziemi krakowskiej, wyd. A. Z. Helcel, w: Starodawne Prawa Polskiego Pomniki, t. II, Kraków 1870.

Zbiór Dokumentów Małopolskich, cz. IV, wyd. S. Kuraś i I. Sułkowska-Kuraś, WrocławWarszawa-Kraków 1969.

\section{Opracowania}

Abraham Władysław, Jakób Strepa arcybiskup halicki 1391-1409, Kraków 1908.

Barącz Sadok, Żywoty sławnych Ormian w Polsce, Lwów 1856.

Bladye' Marian A., Szpital św. Ducha we Lwowie, „Archiwum Historii i Filozofii Medycyny", 62 (1999), z. 1/2, s. 51-66.

Boniecki Adam, Herbarz Polski, t. 1-16, Warszawa 1899-1916.

Dąbkowski Przemysław, Wędrówki rodzin szlacheckich. Karta z dziejów szlachty halickiej, w: Księga pamiątkowa ku czci Oswalda Balzera, t. I, Lwów 1925.

Denys Oksana, Szpital Świętego Ducha we Lwowie, w: Szpitalnictwo w dawnej Polsce, red. M. Dąbrowska i J. Krupp, Warszawa 1998 (Studia i Materiały z Historii Kultury Materialnej, 66), s. 173-184.

Dokumenty Kościoła rzymskokatolickiego Archidiecezji lwowskiej w zasobach Centralnego Państwowego Archiwum Historycznego Ukrainy we Lwowie. Inwentarze, opr., wstępem opatrzył i podał do druku ks. J. Wołczański, Kraków 2007.

Fijałek Jan, Tarłowie. Znamienitego rodu początki i świetność, „Przegląd Historyczny”, 8 (1909) s. 63-88, 167-197, 284-312.

Gilewicz Aleksy, Stanowisko i działalność gospodarcza Władysława Opolczyka na Rusi w latach 1372-1378, Lwów 1929 (nadb. z: Prace historyczne wydane ku uczczeniu 
50-lecia Akademickiego Koła Historyków Uniwersytetu Jana Kazimierza we Lwowie 1878-1928).

Haisig Marian, Sfragistyka szlachecka doby średniowiecza w świetle archiwaliów lwowskich (z 9 tablicami pieczęci), Lwów 1938.

Informator o polonikach w zbiorach rękopiśmiennych Lwowskiej Narodowej Naukowej Biblioteki Ukrainy im. Wasyla Stefanyka, cz. I, opr. M. Matwijów, E. Ostromęcka, Wrocław 2010.

Kania Janusz, Katalog mikrofilmów Ośrodka Archiwów, Bibliotek i Muzeów Kościelnych przy Katolickim Uniwersytecie Lubelskim, „Archiwa, Biblioteki i Muzea Kościelne”, 51 (1985) s. 5-116.

Katalog dokumentów pergaminowych ze zbiorów Tomasza Niewodniczańskiego w Bitburgu, opr. J. Tomaszewicz, M. Zdanek, W. Bukowski, Kraków 2004.

Каталог пергаментних документів Центрального Державного Историчного Архіву ҮРСР у Львові 1233-1799, opr. О. А. Купчинский, Э. И. Ружицкий, Киів 1972.

Kapral Myron, Urzędnicy miasta Lwowa w XIII-XVIII wieku, Toruń 2008 (Spisy urzędników miejskich z obszaru dawnej Rzeczypospolitej, Śląska i Pomorza Zachodniego, t. VII: Ziemie Ruskie, z. 1: Lwów).

Klebowicz Grzegorz, Organizacja parafialna diecezji przemyskiej obrządku łacińskiego w XIV-XVI wieku, Lublin 2013.

Koczerska Maria, O terminologii pokrewieństwa i powinowactwa w polskich źródłach średniowiecznych, w: Genealogia - problemy metodyczne w badaniach nad polskim społeczeństwem średniowiecznym na tle porównawczym, Toruń 1982, s. 27-47.

Krętosz Józef, Organizacja archidiecezji lwowskiej obrządku łacińskiego od XV wieku do 1772 r., Lublin 1986.

Kus Józef, Manowie jarosławscy. Z zagadnień stosunków lennych na Rusi Czerwonej (XIV-XVI w.), „Przemyskie Zapiski Historyczne”, 3 (1985) s. 19-35.

Maleczyński Karol, Urzędnicy grodzcy i ziemscy lwowscy w latach 1352-1783, Lwów 1938.

Пашин Сергей C., Перемышльская шляхта второй половины XIV-начала XVI века. Историко-генеалогическое иследование, Тюмен 2001.

Pilnáček Josef, Rody starého Slezska, díl. 3, Brno 1991.

Потимко Оксана, Развиток медицины у Львові в XIV-XVIII ст.: література, проблемы, дискусії, Львів 2012.

Потимко Оксана, Шпиталі Львова XIV-XVIII століть (Історіографічні спостереження), „Записки Наукового Товариства імені Шевченка”. Праці Комісії спеціальних (допоміжних) історичних дисциплін, 252 (2006) s. 228-268.

Потимко Оксана, Шпиталі Львова під опікою магістрату (XIV-XVIII ст.), „Лікарський збірник”. Нова серія, 10 (2002) s. 38-50.

Rasp Carl W., Beschreibung des städtlichen Bürgerspitals St. Lazar in Lemberg „Archiv für österreichische Geschichte", 43 (1870) s. 505-544.

Semkowicz Władysław, O pochodzeniu i rozsiedleniu rodu Amadejów w Polsce, „Miesięcznik Heraldyczny”, 5 (1912), 9-10, s. 139-143.

Sękowski Roman, Herbarz szlachty śląskiej, t. 4, Katowice 2005.

Sękowski Roman, Udział rycerstwa śląskiego w rządach i kolonizacji Rusi Czerwonej przez Władysława Opolczyka - problemy genealogiczne i rozeznanie wstępne, w: Władysław Opolczyk jakiego nie znamy. Próba oceny w sześćsetlecie śmierci, red.

A. Pobóg-Lenartowicz, Opole 2001, s. 115-135.

Skoczek Józef, Ze studiów nad średniowiecznym Lwowem, Lwów 1928 
Słoń Marek, Szpitale lwowskie w wiekach średnich, „Przegląd Historyczny”, 85 (1994) z. 3, s. 221-237.

Słownik geograficzny Królestwa Polskiego i innych krajów słowiańskich, red. F. Sulimierski, B. Chlebowski, W. Walewski, t. I-XV, Warszawa 1880-1902.

Słownik staropolskich nazw osobowych, t. VI-VII, red. W. Taszycki, Wrocław-WarszawaKraków-Gdańsk-Łódź 1981-1987.

Sochacka Anna, Własność ziemska w województwie lubelskim w średniowieczu, Lublin 1987.

Sochacka Anna, Przed nadaniem prawa miejskiego, w: Dzieje Końskowoli, red. R. Szczygieł, Lublin 1988, s. 21-34.

Sochacka Anna, Ziemia lubelska pomostem w migracji szlachty polskiej na Ruś w późnym średniowieczu, w: Sochacka Anna, Regimen. Dominium. Societas nobilium. Z dziejów gospodarki, administracji i polityki w Lubelskiem w średniowieczu, Lublin 2014, s. 223-246.

Sperka Jerzy, Otoczenie Władysława Opolczyka w latach 1370-1401. Studium o elicie władzy w relacjach z monarchą, Katowice 2006.

Sperka Jerzy, Z dziejów migracji rycerstwa śląskiego na ziemie Rusi Koronnej, w: Narodziny Rzeczypospolitej. Studia z dziejów średniowiecza i czasów wczesnonowożytnych, red. W. Bukowski, T. Jurek, t. I, Kraków 2012, s. 519-548.

Sperka Jerzy, Zarys migracji rycerstwa śląskiego na ziemie Rusi Koronnej w okresie panowania Władysława Jagiełł, w: Княжа доба: історія і культура, red. Л. Войтович, вип. 5, Львів 2011.

Spież Jan A., Trzy niedocenione czternastowieczne dokumenty z archiwum dominikanów w Żółkwi, w: Narodziny Rzeczypospolitej. Studia z dziejów średniowiecza i czasów wczesnonowożytnych, t. I-II, red. W. Bukowski, T. Jurek, Kraków 2012, t. II, s. $1305-$ 1329.

Szweda Adam, Jurkowscy herbu Grzymała. Przyczynek do dziejów osadnictwa polskiego na Rusi Czerwonej, w: Venerabiles, nobiles et honesti. Studia z dziejów społeczeństwa Polski średniowiecznej, Toruń 1997, s. 281-290.

Szymański Józef, Herbarz średniowiecznego rycerstwa polskiego, Warszawa 1993.

Szyszka Janusz, Formowanie i organizacja dóbr monarszych w ziemi lwowskiej od połowy XIV do początku XVI wieku, Kraków 2016.

Szyszka Janusz, Monarsze nadania dóbr ziemskich na rzecz mendykantów i innych instytucji kościelnych w ziemi lwowskiej w średniowieczu, w: Inter oeconomiam caelestem et terrenam. Mendykanci a zagadnienia ekonomiczne, red. W. Długokęcki, T. Gałuszka, R. Kubicki, A. Zajchowska, Kraków 2011 (Studia i Źródła Dominikańskiego Instytutu Historycznego w Krakowie, 9), s. 239-257.

Trajdos Tadeusz M., Dobroczyńcy mendykantów średniowiecznego Lwowa, w: Społeczeństwo Polski średniowiecznej. Zbiór studiów, t. VII, red. S. K. Kuczyński, Warszawa 1999, s. 219-254.

Trajdos Tadeusz M., Kościół katolicki na ziemiach ruskich Korony i Litwy za panowania Władysława II Jagiełły (1386-1434), t. 1, Wrocław 1983.

Trawka Renata, Dokument Władysława Opolczyka dla najstarszego lwowskiego szpitala, w: Ecclesia - Regnum - Fontes. Studia z dziejów średniowiecza, Warszawa 2014, s. $240-250$.

Trawka Renata, Z badań nad kancelarią arcybiskupów halicko-lwowskich. Formularz dokumentów Jakuba Strepy (w druku). 
Tylus Stanisław, Dwa dokumenty z 1521 roku (Malechów i Rodatycze - archidiecezja lwowska), w: Ku prawdzie w miłości. Księga pamiątkowa poświęcona Księdzu Biskupowi Profesorowi Janowi Śrutwie, red. S. Koczwara, Lublin 2002, s. 95-101.

Tylus Stanisław, Fundacje kościołów parafialnych w średniowiecznej archidiecezji lwowskiej, Lublin 1999.

Wilamowski Maciej, Familia dworska Piotra i Andrzeja Odrowążów Sprowskich, wojewodów i starostów ruskich, w: Polska i jej sąsiedzi w późnym średniowieczu, red. K. Ożóg, S. Szczur, Kraków 2000, s. 273-322.

Wilamowski Maciej, Strepa (Strzemię) Jakub, w: Polski Słownik Biograficzny, t. 44, Kraków 2006-2007, s. 318-324.

Wojciechowski Leszek, Fundacje kościelne Władysława Opolczyka, w: Książę Władysław Opolczyk. Fundator klasztoru Paulinów na Jasnej Górze w Częstochowie, red. M. Antoniewicz, J. Zbudniewek, Warszawa 2007, s. 31-95.

Wolff Adam, Projekt instrukcji wydawniczej dla pisanych źródeł historycznych do połowy XVI wieku, „Studia Źródłoznawcze”, 1 (1957) s. 155-184.

Wroniszewski Jan, Ród Rawiczów. Warszowice i Grotowice, Toruń 1992.

Zahajkiewicz Marek T., Zagadnienie gromadzenia dokumentacji źródłowej do badań nad dziejami Kościoła łacińskiego na wschodnich ziemiach kresowych dawnej Polski, „Archiwa, Biblioteki i Muzea Kościelne”, 61 (1992) s. 145-166. 


\title{
TWO UNKNOWN MEDIEVAL DOCUMENTS CONCERNING THE HISTORY OF THE HOLY SPIRIT CHURCH IN LVIV
}

\begin{abstract}
Summary
In the W. Stefanyk Library of the National Academy of Sciences of Ukraine in Lviv, under the reference number: Fond 5, op. 1, spr. 2155, there is a 16th-century manuscript, which contains, among others, the copies of several documents of the 14th and 15th centuries. The documents were prepared on the initiative of Adam Mniszkowski, a provost of the Holy Spirit Hospital and a prebendary of St. Catherine's Chapel at the Lviv Low Castle. Among them are two unpublished documents concerning the endowment of the Holy Spirit Church in Lviv. The first of them-produced by the Archbishop of Halicz Jakub Strepa in 1399- confirms that the nobleman Michał of Malechów gave the rector of the mentioned church an annual rent from the income of the inn in Malechów. The other document was prepared in 1405 by Jakub, a rector of the Holy Spirit Church in Lviv and a judicial vicar of Halicz. He gave Stanisław Żelko, a village leader assistant, the meadow in Sroki together with the forest and the oak tree area with the aim of making it arable land in exchange for the annual rent paid to each rector of the hospital church after the period of wolnizna (the period during which a settler was exempt from paying duties). An analysis of the form indicates that this latter document was also produced in the office of the Archbishop of Halicz. The list of the witnesses to the document includes representatives of the nobility of Lviv and Przemyśl and the townspeople of Lviv. In addition to the characteristics of the content of the both documents, the article also presents their critical editing.
\end{abstract}

Keywords: the Archbishop of Halicz Jakub Strepa; the judicial vicar of Halicz Jakub; the Holy Spirit Church and Hospital in Lviv; the gentry of the Ruthenian Province in the Middle Ages 